\title{
CZU:001.89:575:581.1:631.52 https://doi.org/10.53040/gppb7.2021.01 \\ CERCETĂRI ÎN GENETICA ȘI FIZIOLOGIA VEGETALĂ: RETROSPECTIVĂ ȘI REALIZĂRI ACTUALE ALE IGFPP
}

\author{
Andronic Larisa, Smerea Svetlana, Cotenco Eugenia \\ Institutul de Genetică, Fiziologie și Protecție a Plantelor, Chișinău, Republica Moldova \\ e-mail: larisa.andronic@igfpp.md
}

\begin{abstract}
The paper presents a synthesis of plant genetics and physiology researches carried out at Institute of Genetics, Physiology and Plant Protection since its founding and during last years, as well as the contributions of researchers who worked during this period. The main research directions are highlighted, notifying the scientific and practical importance for supporting breeding programs and agricultural practice.
\end{abstract}

Key words: genetic resources, hybridization, inbreeding, mutagenesis, gametic selection, biotic and abiotic factors

Bazele cercetărilor în domeniul geneticii şi ameliorării în Republica Moldova au fost întemeiate în Academia de Științe a Moldovei, începând cu anul 1957, odată cu crearea Secției de genetică a plantelor, fondator al cărei a fost academicianul Anatolie Kovarski (1957-1974). Direcțiile de studiu includeau subiecte ce vizau crearea materialului iniţial de ameliorare prin diferite scheme de hibridare, evaluarea embriogenezei și gametogenezei ș.a. În pofida restricțiilor lâsencoviste din acea perioadă au fost dezvoltate mai multe direcţii ale geneticii şi ameliorării cum ar fi hibridarea inter- şi intraspecifică, poliploidia, mutageneza spontană și indusă (radiaţională, chimică şi combinată), androsterilitatea citoplasmatică, aneuploidia. Unele din aceste direcții purtau elemente de pionierat, cunoscând ulterior aprecieri înalte în țară și peste hotare.

Din 1976 își începe activitatea științifică și organizatorică în cadrul Secției de genetică acad. Alexandru Jucenco, în calitate de şef al laboratorului de citogenetică, apoi genetică ecologică (1981). În a doua jumătate a anilor 70 acad. A. Jucenco a fondat şi argumentat concepțiile de fond ale geneticii ecologice a plantelor de cultură, care au prezentat o bază teoretică vastă pentru fundamentarea cercetărilor în genetica și ameliorarea plantelor confirmate prin instituirea Institutului de Genetică Ecologică în 1985, care ulterior ca urmare a mai multor proceduri de modificare a fost reorganizat în Institutul de Genetică, Fiziologie și Protecție a Plantelor. În ulterioara perioadă au fost argumentate direcţiile de cercetare ce includeau elaborarea conceptelor teoretice şi metodelor de extindere ale variabilităţii genetice în scopul ameliorării potenţialului adaptiv al plantelor agricole, elaborarea în această bază a noilor metode de selecţie; studierea naturii genetice a mecanismelor reacţiilor adaptive la nivel molecular, celular, de organism, populaţie, specie şi biocenoză.

În realizarea sarcinilor stabilite un deosebit impact au adus colectivele și școlile științifice. Școala în genetică moleculară a rezistenței plantelor a acad. Anatolie Jacotă a pus bazele în rezolvarea problemelor de evaluare a factorilor genetici implicați în diferenţierea formelor parentale după caracterele cantitative; utilizarea marcherilor morfologici şi biochimici în identificarea rezistenţei plantelor la factori abiotici stresogeni. Utilizând aceste abordări a fost formulat şi argumentat conceptul organizării şi funcţionării sistemului genetic integrat de rezistenţă al plantelor la factorii abiotici nefavorabili.

Rezultatele obţinute în ultimii ani mărturisesc, că cercetătorii institutului au sporit esenţial potenţialul creativ în cercetare, şi în soluționarea problemelor actuale cu impact pentru economia naţională.

Cercetătorii laboratorului Genetica Rezistenţei Plantelor, condus de doctorul Iulia Sîromeatnicov (anterior coordonat de acad. A. Jacotă) în baza hibridării distante şi a embrioculturii au creat forme valoroase de tomate cu rezistenţă sporită la temperaturi extremale, precocitate şi productivitate înaltă. Cercetările s-au soldat cu crearea a 6 soiuri de tomate, dintre care 4 au fost omologate. În vederea creării şi evaluării liniilor consangvinizate şi androsterile de sorg se realizează studierea comparativă a productivităţii şi plasticităţii ecologice a hibrizilor omologaţi de sorg de selecţie autohtonă şi de peste hotare ce includ 121 hibrizi, 119 linii androsterile, 115 linii consangvinizate. Un rezultat de perspectivă reprezintă utilizarea reuşită a heterozigotiei în diferite scheme de hibridare, care a condus la crearea a 5 hibrizi: sorg zaharat (SAŞM 1, SAȘM2), sorg pentru boabe (SAȘM 3, Avantaj), hibridul sorg x iarba de sudan (SAŞM 4). În premieră au fost create linii de porumb cu capacitate haploinductoare pronunţată (15-17\%), în baza că- 
rora au fost create linii dubluhaploide cu capacitate combinativă înaltă la încrucişarea cărora se manifestă un grad majorat de heterozis [20]. În rezultatul cercetărilor hibridologice a fost elaborată metodologia de creare a genotipurilor interspecifice pe baza speciilor genetic distante (Vitis vinifera L. x Muscadinia rotundifolia Michx.) care s-au soldat cu crearea a 9 soiuri interspecifice rizogene de viţă de vie cu caractere valoroase, inclusiv 7 omologate pentru cultivare preponderent în zonele de Centru şi de Nord ale Republicii Moldova, ceea ce permit extinderea arealului de cultivare, totodată şi reducerea numărului de tratamente chimice și contribuie la obţinerea de produse ecologice [1].

Soluționarea problemelor legate de managementul procesului de formare a recoltelor este posibilă numai cu trecerea de la metodele experimentale și empirice la teoretico-experimentale, bazate pe utilizarea procedeelor de simulare a productivității plantelor și sistemelor de expertizare a deciziilor [18]. Ultimele ca mijloc eficient de integrare a cunoștințelor teoretice de formare a productivității plantelor pot fi considerate drept bază pentru perfecționarea metodelor de programare a recoltelor și optimizare a principalilor factori de creștere și dezvoltare a plantelor.

Cercetările fundamentale ce ţin de organizarea moleculară şi expresia genelor specifice organelor reproductive la tomate, porumb şi melandrium fundamentate de prof. N. Barbacar au condus la elaborarea conceptului nou referitor la reglarea expresiei genice la nivel de transcripţie şi translare, în baza căruia au fost identificaţi factori de transcripţie şi molecule specifice de micro-ARN, implicaţi în activitatea funcţională pentru unele gene din sistemul reproductiv la plante. Actualmente, în laboratorul Genetică Moleculară, condus de doctorul Lidia Tumanova s-au obţinut rezultate privind design-ul şi caracteristica parametrilor primerilor pentru identificarea fitopatogenilor Phytoplasma solani şi a fungilor din genul Fusarium graminearum, $F$. avenaceum, $F$. moniliformae, $F$. oxysporum, $F$. solani şi Alternaria alternata, A. solani în diferite organe și la diferite etape ontogenetice la grâu și porumb. Cu utilizarea metodelor nested-PCR și PCR în timp real a fost evaluat spectrul de fungi din probele de material semincer depozitat și realizată identificarea moleculară a fitopatogenilor în semințele culturilor cerealiere, legumicole și leguminoase. Date inovative au fost obținute în urma analizei comparative privind spectrul fitopatogenilor din genurile Fusarium, Penicillium și Aspergillus în probele izolate din semințele genotipurilor cercetate în dependență de soi și durata păstrării, precum și a depistării micotoxinelor în materialul semincer [14].

Direcțiile de bază ale cercetărilor laboratorului Biotehnologii Vegetale, condus de doctorul Liliana Mărîi (fondat și coordonat până în 2011 de dr. V. Bujoreanu), sunt focusate pe aplicarea tehnologiilor in vitro, mutagenezei experimentale bazate pe aplicarea virusurilor, ca factori de inducere a variabilităţii, și/sau radiației gama în obținerea formelor noi de plante de cultură (tomate, orz și grâu). Pentru diferite combinații gazdăpatogen este demonstrată variabilitatea însușirilor cantitative și calitative la descendenții plantelor infectate cu virusuri separat sau în asociere cu radiațiile gama; stabilite particularităţile reacțiilor defensive în dependență de interacțiunea gazdă-virus la nivel histologic și ultrastructural, identificate efecte mutaționale și recombinogene [2], estimat răspunsul oxidativ biochimic și histochimic la stresul biotic și abiotic [12]; apreciată eficiența selecției gametice și posibilitatea aplicării parametrilor grăuncioarelor de polen ca instrument în screening-ul rezistenței genotipurilor la factori de stres hidric sau termic [21]. Evaluarea transgenerativă a răspunsurilor defensive în diferite sisteme de plante-virus au scos în evidență la descendenţii plantelor infectate extinderea variabilităţii genetice. Ca rezultat al utilizării infecțiilor virale au fost obținute genotipuri cu caractere nespecifice formelor parentale ce prezintă transgresii pozitive sau negative. Prin asemenea procedee au fost create două soiuri de tomate (Anona și CisGen) cu îmbinarea însușirilor agronomice valoroase.

Cercetări de o importanță majoră în domeniul geneticii și ameliorării culturilor cerealiere, leguminoase, legumicole se efectuează în laboratorul Genetică Aplicată, condus de profesorul Galina Lupaşcu. În rezultatul investigaţiilor au fost elaborate noi principii genetico-ecologice de identificare şi creare a genotipurilor de grâu comun de toamnă, adaptate la factorii nefavorabili de mediu în condiţiile Republicii Moldova, care au la bază: i) identificarea speciilor de fungi care produc putregaiul de rădăcină, ii) stabilirea gradului de diversitate şi dominanţă a agenţilor cauzali în complexele fungice, iii) determinarea particularităţilor de implicare a factorilor parentali în crearea variabilităţii genetice la plante (acţiuni şi interacţiuni genice, transgresii) [11].

Rezultate originale cu impact științific și economic au fost obţinute în ameliorarea grâului dur de toamnă, triticalelor, ce s-au soldat cu crearea și omologarea a peste 17 soiuri de culturi cerealiere (grâu comun, grâu durum, triticale, secară, ovăz). 
Realizări demne de atenţia producătorilor sunt şi cele din domeniul ameliorării plantelor leguminoase şi legumicole. Pe parcursul anilor de activitate au fost create şi omologate circa 17 soiuri de culturi leguminoase (naut, linte, soia, bob, fasoliţă) şi 10 soiuri de tomate.

Laboratorul Plante Aromatice şi Medicinale, condus pe parcursul mai multor ani de doctorul habilitat Maria Gonceariuc (actualmente dr. Balmuş Zinaida), efectuează cercetări privind crearea şi evaluarea genotipurilor noi de plante aromatice şi medicinale, elaborarea de soiuri şi hibrizi adaptaţi la condiţiile Republicii Moldova, performanţi nu numai din punct de vedere al productivităţii, dar şi a calităţii materiei prime, uleiului esenţial, concretului, datorită concentraţiei sporite a principiilor active şi corelaţiei inedite ale componenţilor [8; 9]. Au fost obţinute linii consangvinizate de $S$. sclarea cu conţinut major de ulei esenţial, rezistente la ger, iernare, secetă, boli cu capacitate combinativă generală şi specifică înaltă. În cadrul laboratorului au fost creați peste 4000 hibrizi de diferite specii, printre care Salvia sclarea, Salvia officinalis, Calendula officinalis, Anethum graveolens, Lavandula angustifolia, Silybum marianum.

Cercetările efectuate pe parcursul activităţii în cadrul geneticii şi ameliorării plantelor aromatice şi medicinale s-au soldat cu crearea şi omologarea a 24 soiuri (salvie, armurariu, mărar, lavandă, calendulă, mentă, cimbru de munte ş.a.), solicitate atât pe piaţa internă, cât şi peste hotarele ţării.

Agrobiodiversitatea și aspectele bioconservării au fost și rămân în toată complexitatea lor obiective prioritare ale institutului. Astfel, în a.1998 prin Hotărârea Guvernului R. Moldova nr.1203 din 14 decembrie a fost creată prima Bancă Naţională de Resurse Genetice. În conformitate cu prerogativele sale, activitatea centrului includea inventarierea, colectarea și achiziționarea mostrelor de plante cultivate, a strămoșilor lor sălbatici de pe teritoriul Republicii Moldova, centre europene și internaționale, instituţii de cercetare în scopul diversificării fondului genetic național, completarea colecțiilor de lucru [6]. În baza Centrului de Resurse Genetice Vegetale din Moldova în 2013 a fost instituit laboratorul Resurse Genetice Vegetale, condus de dr. Anatolie Ganea.

Actualmente colecția deține material genetic în număr de circa 6,5 mii mostre ce aparțin la 36 familii botanice, 147 genuri și 225 specii, inclusiv cele mai importante culturi cerealiere păioase (grâu, secară, orz, triticale etc.), porumb, leguminoase (fasole, năut, bob, latir, linte, fasolița), legumicole (tomate - cca 800 forme, ardei - 80 genotipuri, pătlăgele vinete - 50), aromatice și medicinale (peste 150 mostre).

Conform rezultatelor din ultimii ani s-a efectuat inventarierea populaţiilor unor rude sălbatice ale culturilor pomicole (Prunus avium, Cornus mas, Pyrus pyraster, Malus sylvestris și Corylus avellana) în ecosistemele forestiere din cadrul ocoalelor silvice Bălți, Florești, Edineț, Soroca, Fălești, Briceni, Otaci și Râșcani; executată GPS-poziționarea arborilor și studiate caracterele morfobotanice importante [7]. Au fost obținute date experimentale noi privind caracterizarea, evaluarea complexă ex situ și reproducerea mostrelor de culturi cerealiere, leguminoase, legumicole, tehnice și netradiționale, testarea longevității materialului semincer în scopul pașaportizării germoplasmei pentru includerea în baza de date și amplasarea pe termen lung în Banca de gene. În conformitate cu particularitățile biologice, formele incluse în colecție sunt evaluate şi descrise după parametri morfobiologici, agrobiologici şi ecologo-adaptivi şi clasificate în grupuri după gradul de manifestare a caracterelor valoroase. Genotipurile sunt apreciate în funcţie de rezistenţa la factorii de stres abiotic la diferite etape - gametofit şi sporofit, iar cele de perspectivă sunt incluse în procesele ameliorative. Doar în ultimii ani cercetările la tomate s-au soldat cu crearea şi omologarea a 7 soiuri [19].

Cercetările ştiinţifice în domeniul fiziologiei şi biochimiei au cunoscut fundamentare academică în primii anii de după cel de al doilea război mondial când la Chișinău se organizează filiala Moldovenească de Cercetări Ştiinţifice a AŞ a URSS în cadrul căreia se instituie Secţia de fiziologie şi biochimie a plantelor ce întrunea două laboratoare: Fiziologia Plantelor şi Biochimia Plantelor. Evoluţia conceptelor științifice despre procesele vitale ale plantelor, dezvoltarea agriculturii au pus în faţa cercetătorilor sarcini noi şi complexe. Se resimţea imperios necesitatea unor investigaţii pe bază de sistem, ample şi profunde, organizării unui nucleu ştiinţific, menit să coordoneze realizarea acestor probleme. Ca rezultat, la 16 mai 1961 a fost fondat Institutul de Fiziologie şi Biochimie a Plantelor, ce a devenit unicul centru ştiinţific de coordonare a investigaţiilor în domeniul fiziologiei şi biochimiei plantelor din republică.

Direcţiile principale în primii ani de activitate a institutului au inclus studiul procesului de fotosinteză, ca factor de sporire a productivităţii plantelor; elucidarea particularităţilor fiziologice şi biochimice ale productivităţii plantelor de viţă de vie, pomicole, tehnice şi cerealiere în funcţie de nutriţia minerală şi regimul hidric. Pe parcursul anilor, au fost înaintate şi ştiinţific argumentate teorii, concepţii şi ipoteze, ce au contribuit la deschiderea a noi direcţii de cercetare, aducând o pondere substanţială pentru ştiinţele bio- 
logice. Baza reperelor ştiinţifice ale institutului au fost puse de cunoscuţi savanţi, fondatori ai unor studii consolidate, aducând o pondere substanţială în dezvoltarea ştiinţelor biologice: acad. S. Toma, m. cor. C. Moraru, acad. B. Matienco, acad. Gh. Șișcanu, m. cor. N. Balaur.

Investigațiile fundamentale realizate sub conducerea academicianului Simion Toma privind studiul microelementelor ca vectori ai proceselor biologice la plante, au condus la elucidarea mecanismelor fiziologice şi biochimice de creştere a plantelor și sporirii rezistenţei la acţiunea factorilor stresogeni, elaborarea principiilor de optimizare a nutriţiei minerale în vederea manifestării mai ample a potenţialului genetic de rezistență și productivitate al plantelor de cultură.

Rezultate impunătoare în domeniul studierii fiziologiei rezistenţei plantelor la factorii nefavorabili au obţinut cercetătorii laboratorului Nutriţie Minerală și Regim Hidric al Plantelor, coordonat de profesorul Anastasia Ștefârță. Prin studiul fiziologiei rezistenţei plantelor şi metabolismului hidric au fost relevate particularităţi ale inducţiei proceselor de autoreglare a metabolismului hidric în condiţii nefavorabile în funcţie de caracterul stres-factorului, viteza apariţiei și evoluiţiei stării de stres şi rezistenţa plantelor [16]. Au fost elaborate procedee şi metode de estimare complexă ale rezistenţei plantelor la secetă, arşiţă, salinitate, de reglare exogenă ale rezistenţei prin aplicarea substanţelor biologic active. În acest laborator se realizau cercetări la nivel molecular, celular, de organ și organism vizând elucidarea mecanismelor asociate de adaptare a plantelor la secetă, salinizare, deficit de elemente nutritive, și regim termic nefavorabil. Prin studii experimentale ample a fost evaluată cauza perturbării proceselor vitale și afectării structurilor celulare ale plantelor în condiţii nefavorabile, consecințele deshidratării țesuturilor în condiții de arșiță și metode de sporire a toleranței plantelor la secetă. Totodată, aceste cercetări de importanță majoră pentru știinţele biologice și cu impact pentru țară nu au obținut susținere financiară ca urmare a concursului proiectelor de cercetare organizat în 2019.

Studiile structurale şi ultrastructurale dezvoltate în cadrul școlii de biologie celulară fundamentată de academicianul Boris Matienco sunt continuate în cadrul laboratorului Fiziologia Plantelor Pomicole și Maturării Fructelor (șef laborator dr. hab. Nicolae Bujoreanu). Vectorul investigațiilor a fost trasat pe problemele asociate maturării și păstrării fructelor și dezvoltat în continuare prin direcțiile aprobate în fiziologia și biochimia, în particular fotosinteza plantelor pomicole. Pentru evaluarea calității, capacităţii de păstrare, rezistenței fructelor culturilor pomicole la bolile fungice, dereglările fiziologice și deshidratării țesuturilor sunt utilizate metode fiziologice, patofiziologice, biochimice, anatomice și tehnologice. În baza studiului particularităţilor structurale ale ţesuturilor fructelor de măr, păr și prun (stratului cerifer, cuticulei, epidermei, hipodermei, mezocarpului), conţinutului acizilor titrabili şi celui ascorbic, glucidelor, polizaharidelor membranelor celulare, alcoolului etilic, acetaldehidei, etilenei, oxigenului, dioxidului de carbon, elementelor minerale, peroxidazei şi polifenoloxidazei sunt elaborate tehnologii de creștere direcționată a fructelor [3]. Cercetările ce țin de încetinirea proceselor de maturare-senescență și menținerea la un nivel înalt al calităţilor organoleptice la fructe sunt efectuate prin aplicarea păstrării în atmosferă obișnuită, controlată și îmbogăţită cu vapori ai inhibitorilor de sinteză a etilenei (de ex. „Fitomag”).

Sub conducerea academicianului Gheorghe Şişcanu în baza evaluării activităţii aparatului fotosintetic şi a metabolismului centrelor de atracţie pe parcursul perioadei de vegetaţie au fost obţinute rezultate privind potenţialul aparatului fotosintetic la reprezentanţii diferitor grupuri de soiuri omologate de culturi pomicole şi viticole, a fost evaluată intensitatea fotosintezei şi durata activităţii ei în condiţii nefavorabile de cultivare, eficacitatea fotosistemei II, în scopul utilizării acestora în procesul de diagnosticare a productivităţii şi rezistenţei ecologice a genotipurilor analizate [15]. În rezultatul investigaţiilor ştiinţifice au fost elaborate şi introduse în teoria productivităţii fotosintetice noi principii şi noţiuni, care au adus o importantă contribuţie în studierea particularităţilor funcţionării aparatului fotosintetic la plantele de cultură.

Cercetările ce vizează biochimia plantelor au fost inițiate acum cca 65 ani, prin crearea grupului de biochimie din cadrul laboratorului de Fiziologie și Biochimie a Plantelor a Filialei Moldoveneşti a Academiei de Științe a USSR. Studiile iniţiale au fost focusate asupra aprecierii biochimice a fructelor culturilor pomicole și legumicole în funcţie de termenul de maturizare şi tehnologiile de cultivare, majorarea capacităţii şi termenilor de păstrare a lor. O nouă amploare a fost marcată prin crearea Centrului de Biotehnologii avansate, ulterior laboratorul Biochimia Plantelor, fondat și coordonat pe parcursul mai multor ani de profesorul Alexandru Dascaliuc (actualmente dr. Tatiana Călugăru-Spătaru). Cercetările complexe din ultimii ani au asigurat fundamentarea metodologiei privind testarea accelerată a rezistenţei la factorii de stres prin determinarea rezistenţei primare a plantelor la acţiunea temperaturilor înalte şi joase, ceea ce permite estima- 
rea separat a rezistenţei adaptive şi rezistenţei prin evitare şi determinarea rezistenţei totale a genotipurilor în condiţii de stres [4]. Metoda elaborată permite: i) optimizarea selecţiei şi repartizarea soiurilor după toleranța la factori termici; ii) aprecierea capacităţii adaptive a plantelor la diferite etape ale ontogenezei; iii) determinarea schimbării rezistenţei totale a plantelor faţă de arşiţă și ger în urma adaptărilor sezoniere; iv) estimarea influenței vârstei asupra rezistenţei şi capacităţii de recuperare a deteriorărilor provocate de factorii de stres; v) elaborarea unor teste biochimice şi biofizice, care permit de a aprecia rapid atât schimbarea rezistenţei primare, cât şi a capacităţii de recuperare a deteriorărilor provocate de arşiţă şi ger. Pentru evitarea şi diminuarea acţiunii nocive a factorilor de stres (temperaturilor excesive şi a secetei), precum şi stimularea productivităţii sunt elaborate și recomandate metode de sporire a viabilității plantelor datorită tratării seminţelor înainte de semănat sau a plantelor pe vegetaţie prin utilizarea substanţelor biologic active (Reglalg) [5]. De o valoare majoră sunt rezultatele ce demonstrează contribuția biostimulatorilor naturali în utilizarea mai eficientă a substanțelor de rezervă din semințele genotipurilor de grâu, porumb, stejar și fag, calusului de Rhodiola rosea L. ce duc la sporirea „costului” alocat pentru supraviețuire și creștere, ceea ce în final asigură sporirea capacității adaptive a plantelor față de acțiunea temperaturilor extremale. În cadrul laboratorului se elaborează metode de micropropagare şi conservare în cultura in vitro a unor specii de plante medicinale, ornamentale şi de cultură ce sunt pe cale de dispariţie sau multiplicarea cărora prin metode convenţionale este anevoioasă sau lentă. În prezent au fost elaborate metode de micropropagare a plantelor de Rhodiola rosea L., Orhideea spp., Gerbera L., Lavandula spp., Actinidia argura, etc.

Un obiectiv aparte constituie evidențierea surselor de substanţe biologic active (SBA) cu perspectivă de utilizare în agricultură, medicină. Această direcție a fost iniţiată și fundamentată de profesorul Pavel Chintea și dezvoltată în laboratorul Bioreglatori Naturali, actualmente coordonat de doctorul Raisa Ivanova. Pentru fortificarea plantelor de cultură față de factorii depresivi de mediu și modularea reactivităţii la condițiile extremale au fost obţinute cca 500 substanțe biologic active (SBA) din clasele glicozidelor steroidice, fenolice și iridoidice, care sunt implementate cu succes în practică. Din patru preparate (Ecostim, Mestim, Moldstim, Pavstim) anterior înregistrate pentru aplicare în agricultură, trei (Ecostim, Mestim, Pavstim) sunt reînregistrate ca regulatori de creştere (certificate de omologare nr. 21-04-22-06-0951; 21-04-22-06-0952; 21-04-22-06-0953 din 22.04.2021). Ca surse de SBA sunt utilizate diferite specii de plante cultivate, precum și reprezentanţi ai florei spontane, în special din familia Scrophulariaceae. Doar în ultimii ani au fost obţinute extracte integrale şi/sau separtate după principii activi din Veronica officinalis, Veronica spiicata, V. spuria, V. teucrium, Linaria vulgaris, L. genistifolia, Verbascum densiflorum, V. plomoides, Melampirum nemorosum, Scrophularia nodosa, Polygonum sachalinense, Juglans regia, Carthamus tinctorius, Paulownia tomentosa, Juniperus sabina şi Phytolacca americana, stabilită componența chimică a extractelor și structurile chimice ale substanțelor, precum şi cercetată activitatea lor biologică [13]. In condiții de cultivare în câmp a plantelor cerealiere (grâu, triticale, porumb), legumicole (tomate, castraveți, ceapă, morcov, varză) şi medicinale (in obişnuit, șofrănel, schinduf și susan) a fost testată acţiunea stimulatoare a glicozidelor asupra germinării seminţelor şi creşterii embrionare, ceea ce asigură obținerea unor plantaţii omogene şi uniforme, precum şi sporirea productivităţii şi îmbunătăţirii calităţii comerciale a producţiei finale. A fost demonstrat, că sub influența preparatului Moldstim consumul substanțelor de rezervă din endospermul semințelor de porumb este proporțional cu rezistența la temperaturi înalte, iar restabilirea proceselor de creștere a plantelor în fazele iniţiale de creștere a fost mai pronunțată la hibrizii mai puțin viguroși [10]. Efectul benefic al tratării cu SBA (Moldstim și genistifoliozida) a fost stabilit și la germinarea jirurilor și creșterea plantelor de fag, sarcină importantă stabilită în proiectul în derulare ce are ca obiectiv elaborarea metodei de apreciere a rezistenței plantelor de stegar și fag.

De o valoare majoră pentru fortificarea cercetărilor în biologia vegetală sunt realizările ce demonstrează importanța aplicării paradigmei de evaluare integrată a plantelor sub aspecte genetice, fiziologice și de protecție. Dovadă elocventă servesc realizările de sinergism dintre mijloacele microbiologice cu factorii naturali (preparate polifuncționale), precum și extinderea spectrului de mijloace de protecție biologică pentru sistemele de agricultură convenţională și ecologică [17].

Prioritățile de cercetare în direcția protecției plantelor pe parcursul ultimilor ani au fost orientate spre elucidarea problemelor fundamentale şi aplicative aşa ca evaluarea componenţei specifice a particularităților biologice şi ecologice ale entomofagilor, principalelor specii de dăunători a culturilor de câmp; crearea colecției de artropode răpitoare şi parazite; estimarea pragurilor de pagubă economică şi elaborarea metodelor de prognozare a dezvoltării speciilor de organisme dăunătoare cu impact economic negativ. Este demonstrată utilizarea insectelor utile ce permite reducerea/ excluderea utilizării preparatelor chimice de protecție a 
plantelor din sere şi obținerea producției ecologice. Urmare a studiilor experimentale ample au fost elaborate și reomologate 9 preparate biologice, inclusiv 6 produse feromonale și 3 de origine virală/bacteriană destinate pentru protecția diferitor culturi agricole în combaterea dăunătorilor şi bolilor.

Pe parcursul anilor IGFPP și-a dovedit importantă majoră în impulsionarea cercetărilor științifice, diversificarea domeniilor de investigații, dezvoltarea cercetărilor fundamentale, pregătirea cadrelor de înaltă calificare, sporirea activității de inovare și transfer tehnologic, devenind actualmente unicul centru știinţific de cercetări fundamentale și coordonare a investigațiilor în domeniile geneticii, fiziologiei, biochimiei și protecției plantelor din republică.

\section{BIBLIOGRAFIE}

1. ALEXANDROV, E. Crearea genotipurilor interspecifice rizogene de viţă-de-vie. Chişinău: Tipografia "Lexon-Prim, 2020. $232 \mathrm{p}$.

2. ANDRONIC, L. Bazele citogenetice ale variabilității genetice la plantele de cultură în condiții de patogeneză virală. Chişinău: Tipografia „Print-Caro”, 2020. 236 p.

3. BUJOREANU, N., CHIRTOCA, A., BOUBĂTRĂN, I. Cultivarea direcționată a fructelor de păr pentru păstrare îndelungată. Chișinău: Tipografia "Print-Caro", 2020, 100 p.

4. DASCALIUC, A. The use of systemic approach for obtaining and practical application of biostimulants in agriculture. In: Биологически активные препараты для растениеводства: научное обоснование - рекомендации практические результаты: материалы 16-й междунар. науч.-практ. конф., Минск, 2020, с. 61-63.

5. DASCALIUC, A., VOINEAC, V., RALEA, T., JELEV, N. The influence of biostimulant Reglalg on plants resistance to abiotic and biotic stress factors. In: Buletinul AȘM. Ştiinţele vieţii. 2018, Nr, 3(336), p. 76-82.

6. GANEA, A. Elaborarea programului naţional al Republicii Moldova privind conservarea şi utilizarea durabilă a resurselor genetice vegetale pentru alimentaţie şi agricultură. In: Agronomie şi agroecologie. 2018, Vol. 52(1), p. 218-225.

7. GANEA, A. Perspectivele conservării in situ a părului pădureț în Republica Moldova. In: Integrare prin cercetare şi inovare: conferinţa şt. naţ. cu participare intern., Chişinău, 10-11 noiem. 2020, Chişinău, 2020, p. 179-182.

8. GONCEARIUC, M. Cultivarea soiurilor de plante medicinale și aromatice în scopul diminuării impactului negativ al secetei. In: Biotehnologii avansate - realizări şi perspective: simpozion ştiinţific naţional cu participare internaţională. Ediţia V-a. Chișinău, 2019. p. 154.

9. GONCEARIUC, M. Lavanda: Descriere, biologie, taxonomie, componenţa chimică, utilizare, acţiune terapeutică, soiuri, hibrizi, tehnologii de cultivare. Chişinău: Tipografia "Print-Caro", 2018, 131 p.

10. IVANOVA, R. A., BOROVSKAIA, A. D. Study of influence of bioregulator Moldstim on intrinsic resistance of maize to supra optimal temperatures. The Bulletin of Kharkiv National Agrarian University. Series Biology. Special Issue. Proceedings of International Scientific Conference "Plant Stress and Adaptation”, Kharkiv 2021, p. 193-194.

11. LUPAŞCU, G. Putregaiul de rădăcină la grâul comun de toamnă. Chişinău: Tipografia "Print-Caro", 2020, 120 p.

12. MARII, L., ANDRONIC, L., SMEREA, S. Transgenerational effects of viral infections in the manifestation of quantitative traits in the offspring of tomato infected plants. In: Buletinul ASM. Ştiinţele vieţii. Chişinău, 2020, 2(341), p. 72-79.

13. MASCENCO, N.; GUREV, A.; LUPASCU, G.; GORINCIOI, E. Iridoid glycosides from Linaria genistifolia (L.) in biological control of soil-borne fungal pathogens of wheat and some structure consideration. In: Chemistry Journal of Moldova. General, Industrial and Ecological Chemistry, 2015, 10 (1), p. 57-63.

14. MITINA, I., MITIN, V., TUMANOVA, L. et. al. Detection and quantification of mycotoxigenic fungi in maize by Real-time PCR. In: Journal of Engineering Science. 2020, 27(3), p. 225-231.

15. ȘIȘCANU, Gh. Fotosinteza și funcționalitatea sistemului donor-acceptor la plantele pomicole. Chișinău: Tipografia AȘM, 2018,316 p.

16. ȘTEFÂRȚÃ̉, A., BRĂNZÃ, L., VRABIE, V., ALUCHI, N. Fiziologia stresului, adaptării și rezistenței la secetă a plantelor de cultură. Chișinău: Tipografia AȘM, 2017, 372 p.

17. VOLOŞCIUC, L. Agricultură conservativă (manual pentru producători agricoli și formatori). Chişinău: Tipografia "Print-Caro", 2020, 203 p.

18. БОТНАРЬ, В. Ф. Основы управления технологическими процессами возделывания овощных культур в открытом грунте. Chişinău: Tipografia "Print-Caro", 2018, 347 c.

19. МАКОВЕЙ, М. Селекция томата на устойчивость к стрессовым абиотическим факторам с использованием гаметных технологий. Chişinău: Tipografia "Print-Caro", 2018, 473 c.

20. МИХАЙЛОВ, М.Э. Применение дигаплоидных линий в генетическом анализе и в селекции кукурузы. Chişinău: Tipografia "Print-Caro", 2018, 232 c.

21. САЛТАНОВИЧ, Т.И., ДОНЧИЛЭ, А.Н. Идентификация устойчивых генотипов томата с использованием гаметных технологий. В: Овощи России. 2020, (4), с. 50-54. 